\title{
High-resolution palynological analysis in Lake Sapanca as a tool to detect recent earthquakes on the North Anatolian Fault
}

Suzanne A. G. Leroy*, Institute for the Environment, Brunel University, Uxbridge UB8 3PH (West London), UK

Sonay Boyraz and Alper Gürbüz, Ankara Üniversitesi, Mühendislik Fakültesi, Jeoloji Mühendisliği Bölümü, 06100 Tandoğan, Ankara, Turkey

* corresponding author: tel: +44-1895-266087; fax: +44-1895-269761;

suzanne.leroy@brunel.ac.uk

\section{Abstract}

High-resolution palynological analysis of a 38-cm-long core collected from Lake Sapanca, northwest Turkey, reveals large earthquakes that occurred during the second half of the $20^{\text {th }}$ century along the North Anatolian Fault Zone. Four events have disturbed the lacustrine sedimentary sequence. Three of the four events are historical earthquakes in 1999 in Izmit, 1967 in Mudurnu and 1957 in Abant. These events are recorded in the core by turbiditic deposits and reworked sediment and by low overall palynomorph concentrations but high values of thick-exined pollen, fern spores and fungal spores. Palynomorphs in the event beds have been grouped based on their associations in modern moss, river and lake samples. The inferred mechanisms of transport and sources for the palynomorphs are: 1- lake sediment displaced by slump, 2- collapsed shoreline sediment owing to seiche, waves and sudden lake level changes, 3- subsidence of deltas and 4river-transported soil and sediment from upland areas. The 1999 Izmit earthquake is only weakly recorded by palynomorphs, probably due to recent engineering control on the rivers. The 1967 Mudurnu earthquake had the strongest effect on the lake, introducing successive packages of sediment to the centre of the lake from underwater slopes, the lakeshore and rivers. 


\section{Introduction}

Palaeoseismology traditionally relies on geomorphology, trench data, stratigraphy and radiocarbon dating to reconstruct ancient earthquakes and to infer their magnitude and recurrence times (Kürçer et al., 2008; Pantosti et al., 2008; Vandenberghe et al., 2009). Recent research has focused on palaeoseismic records from lacustrine settings, an approach still hardly mentioned in reviews of methodologies used in earthquake geology (Caputo and Helly, 2008; Caputo and Pavlides, 2008). Lakes offer a more continuous record of sedimentation than trenches, which often are in alluvial/colluvial settings with coarse sediment and hiati. Magnetic susceptibility, sedimentary structures, geochemistry and particle size analyses are the preferred tools for identifying earthquakes in lake sediments sequences (Doig, 1986; Becker et al., 2005). The new field of earthquake limnology however is rapidly developing.

Palynological analysis is not commonly used in palaeoseismological investigations. When it is used, it is as a chronological and palaeoecological tool. Coseismic uplift or subsidence may alter vegetation, which in turn may be registered in pollen assemblages and concentrations within sediments (Mathewes and Clague, 1994; Mirecki, 1996; Hughes et al., 2002). Exposure of new land following an earthquake can also be indicated in pollen diagrams by the presence of pioneer plants (Cowan and McGlone, 1991).

Coseismically-triggered landslides may introduce large quantities of reworked sediment into lakes and seas, producing beds with distinctive microfossil assemblages such as foraminifera. Syvitski and Schafer (1996), in a basinwide failure of the Saguenay Fjord, used several biological tracers to identify local and distal sediment sources. A crude Pinus/Picea ratio is used to indicate sediment reworking.

Turkey is seismically active with a $35-70 \%$ probability that Istanbul, its megalopolis, will be struck by a large earthquake in the next 30 years (Parsons, 2004). Thus studies that provide a better understanding of the seismicity of the country are of considerable interest. In this paper, we report the results of a study of cores taken in Lake Sapanca, which is about $90 \mathrm{~km}$ east of Istanbul and within the Marmara region, one of the most industrialized 
parts of northwestern Turkey. This region has one-third of the industry and one-fourth of the population of Turkey (Union of Municipalities of the Marmara Region, no date). The North Anatolian Fault Zone (NAFZ) (Figs 1a and b), which extends through Lake Sapanca, is a strike-slip fault that has generated several disastrous earthquakes in the past century (Straub et al., 1997).

Corroded pollen and spores can be used as indicators of changing lake sediment sources and catchment disturbance, as has been done in palynological studies of some New Zealand lakes owing to major disturbance in the lake catchment, such as volcanism, fire and deforestation (Wilmshurst and McGlone, 2005a). Pollen concentrations may reflect dilution of the lake sediment by input of soil by erosion (Beaudoin and Reasoner, 1992). The identification and the use of fungal spores and a range of non-pollen palynomorphs (NPP) are still developed; but some of these palynomorphs have already been established as excellent indicators of soil erosion (Mudie et al., in press).

Palynology is here explored as a taphonomic indicator of earthquakes. Special attention is given to pollen and NPP sources, preservation and concentration modifications in a cored sediment sequence. We distinguish palynomorph assemblages derived from vegetation in the hills and mountains surrounding the lake from those derived from a variety of sedimentary deposits in lowlands bordering the lake. The steep slopes bordering the lake and within the lake ensures that the lacustrine depocentre is exposed to sediment derived from soil erosion and slope wash.

\section{Physical setting and background information}

\subsection{Lake Sapanca}

Lake Sapanca $\left(40^{\circ} 43^{\prime} \mathrm{N}, 30^{\circ} 15^{\prime} \mathrm{E}\right)$ has a volume of about $10^{9} \mathrm{~m}^{3}$ and a surface area of $49 \mathrm{~km}^{2}$, which is nearly five times smaller than the catchment area, which is $250 \mathrm{~km}^{2}$ (Morkoç et al., 1998) (Figs 1b, 2 and 3). The lake surface is $31 \mathrm{~m}$ above sea level (asl) and its maximum depth is 55 m. Lake levels, which have been monitored since October 1955, fluctuate between $\sim 30$ and $\sim 32.5 \mathrm{~m}$ asl. In general, the lake is lowest in October and highest in April (Elektrik İşleri Etüd İdaresi, 2002). The lake is warm, 
monomictic and holomictic (Morkoç et al., 1998). Surface waters cool to 6.5 ${ }^{\circ} \mathrm{C}$ by late winter and then warm steadily to $26^{\circ} \mathrm{C}$ in late summer. Deep-water temperatures range from 6.5 to $10.0^{\circ} \mathrm{C}$ throughout the year (Morkoç et al., 1998).

Fifteen rivers, many of them ephemeral, feed the lake with the largest inflows from the south. The rivers flow in incised, steep-walled valleys, across alluvial fans and delta plains into the lake (Gürbüz and Gürer, 2008b; Gürbüz and Leroy, in press). Some groundwater inflow has also been noted (Ertürk, 1994; Gürbüz and Gürer, 2008a). Dams were constructed on the rivers in the 1970 s to prevent coarse sediment from reaching the lake and gradually filling it, which would reduce the supply of water to the nearby town of Adapazarı (Devlet Su İşleri, 1984; Gürbüz and Gürer, 2008a). Lake Sapanca discharges via the Çark River on the northeast shore into Sakarya River. A dam was built at the lake outlet in 1979 to regulate the water level (Akkoyunlu and İleri, 2003; Gürbüz and Gürer, 2008a). The Sakarya River outflows into the lake during periods of high discharge via the marshy floodplain that separates the two (Russell, 1954; Doğan, 2004; Gürbüz and Leroy, in press).

The margins of the lake mostly consist of coalesced alluvial fans, terraces, Holocene beaches and prograding delta fans at the mouths of the rivers (Rathje et al., 2004). Nearshore lake sediments are sand, whereas sediments in the deepest part of the lake are mainly silt (Gürbüz and Gürer, 2008a). Clayey sediment is restricted to the northeast part of the lake. Gürbüz and Gürer (2008a) suggest that the deposition of the fine sediment in shallow water at the northeast end of the lake results from regulation of the outflow. Another possible explanation is that the fine sediment is deposited when the Sakarya River flows into the lake. Gürbüz and Gürer (2008a) have also shown that more sediment is deposited off the south shore of the lake than the north shore, due to the larger catchment sizes and steeper slopes in the hills and mountains to the south (Fig. 3).

The Samanlı Mountains, which have a maximum elevation of $1602 \mathrm{~m}$ at Kelltepe, lie south of the lake (Fig. 3). Gentle hills border the lake on the north (Gürbüz and Gürer, 2008b; Gürbüz, 2009).

Lake Sapanca occupies a pull-apart basin created by a step-over along the NAFZ (Barka et al., 2000; Lettis et al., 2000; Rathje et al., 2004; Gürbüz 
and Gürer, 2008a, 2008c, 2009). The basin is bordered on the north by the Sapanca fault segment of the NAFZ and on the south by a diffuse zone of normal faults (Lettis et al., 2002). It lies at the intersection of the Kocaeli fault which ruptured on 17 August $1999\left(M_{w} 7.4\right)$ and the southern branch of the NAF, which most recently slipped during the 22 July $1967\left(M_{w} 7.0\right)$ Mudurnu Valley earthquake (Lettis et al., 2002; Gürbüz and Gürer, 2008b) (Fig. 1b). The May 1957 Abant earthquake (Mw 6.8) had an epicentre a few kilometres east of the lake (Müller et al., 2003). The 20 June 1943 Hendek earthquake (magnitude of Mw 6.4) occurred along the same portion of the fault as the 1999 earthquake (Barka, 1999) and caused much damage at Adapazarı (also called Sakarya), Hendek, Akyazı and Arifiye, just east of Lake Sapanca (Şahin and Tarı, 2000).

Earthquakes on the NAFZ are dominantly strike-slip events, but locally have small components of normal displacement. Large earthquakes on the Sakarya fault segment, east of the lake, produce right-lateral displacements of 2-5 m and vertical displacements of 0.25-0.5 m (Rathje et al., 2004). Normal fault displacements have also occurred during the 1967 Mudurnu valley earthquake (Ambraseys and Zatopek, 1969; Rathje et al., 2004; Gürbüz and Gürer, 2008b).

Subsidence observed along the margins of Lake Sapanca during the 1999 Kocaeli earthquake was mainly due to failure of delta fronts. The most significant failure occurred on the south coast at Hotel Sapanca (Çetin et al., 2002); a smaller failure happened on the north coast at Eşme (Rathje et al., 2004). The earthquake also produced liquefaction, sand boils and riverbank collapse, all of which introduced large amounts of sediment to the lake (Bardet et al., 2000; Çetin et al., 2002).

It is likely that some soil and sediment were introduced into Lake Sapanca during the construction of the national road north of the lake in the 1950s, a railway in 1975 and a motorway along the south shore in the 1980s (Yalçın and Sevinç, 2001). Besides earthquakes and construction, runoff from heavy rainfall can deliver large amounts of sediment to the lake.

\subsection{Climate and vegetation}

Mean annual precipitation and temperature at Adapazarı over the past 
30 years are $830 \mathrm{~mm}$ and $13^{\circ} \mathrm{C}$ respectively (Devlet Meteoroloji işleri Genel Müdürlüğü, General Directorate of State Meteorological Works). Storms with more than $80 \mathrm{~mm}$ of rainfall per day occurred on 3 July $1981(88.1 \mathrm{~mm}), 30$ July 1984 (82.3 mm), 26 June 1999 (127.7 mm) and 24 July $2002(93.7 \mathrm{~mm})$. The mountains south of Lake Sapanca receive much higher precipitation than Adapazarı and snow in winter.

Vegetation in the Lake Sapanca catchment is part of the Euxinian domain (Quézel and Barbéro, 1985). The catchment is 55\% forests and meadows, 33\% agricultural land and 9\% urban and industrial land; $3 \%$ of the land is used for other purposes (Baykal et al., 1996). Most of the land directly bordering the lake is agricultural (Fig. 3). Some open spaces are occupied by macchia, a Mediterranean scrubland (Ceylan, 1990; Yılmaz, 2000). The northern hills support a formation with various species of Quercus and are generally drier and more open than the southern hills and mountains. South of the lake, the Quercus formation is succeeded upward by several altitudinal zones: Carpinus betulus - Castanea sativa - Quercus; Castanea sativa Carpinus betulus; Fagus orientalis forest with Rhododendron ponticus; and Fagus orientalis with Pinus (Fig. 3). Abies bornmülleriana and nordmaniana are present on the highest peaks. Soils around Lake Sapanca have a pH between 6.5 and 7.5 (M. Kibar, personal communication, 2005).

Aquatic plants grow in shallow waters along the south and west shores of Lake Sapanca and adjacent to marshland at the east end of the lake. Phragmites australis, Potamogeton pectinatus, Myriophyllum sp., Najas marina and Ceratophyllum sp. dominate on the south shore (Albay and Akçaalan, 2008). Waters along the north side of the lake are too deep to support significant macrophytic communities.

\subsection{Pollen transport, preservation and concentration}

The processes responsible for deposition of pollen and spores in lake sediment are airborne and water transports and, to a lesser extent, sediment redeposition (Pennington, 1979; Birks and Birks, 1980). Pollen assemblages in river sediments and other high-energy deposits are different from assemblages in lake sediments (Birks and Birks, 1980; Leroy, 1992). The former commonly have more spores, bisaccate pollen such as Pinus and 
heavy grains such as the tetrads of Ericaceae. In a study of a lake in southern France, Andrieu et al. (1997) found higher Pinus percentages, but lower overall pollen concentrations, in slumped sediments than in overlying and underlying "normal" lacustrine sediment. Pollen transported by rivers is derived from direct pollen rain, bank erosion and surface run-off. De Busk (1997) found that surface samples collected near the mouths of rivers in Lake Malawi had a higher ratio of spores to pollen, consistent with derivation of palynomorphs from soils and bank erosion.

Pollen is generally not well preserved in soils unless the soil $\mathrm{pH}$ is less than 5.5 (Pennington, 1979; Birks and Birks, 1980; Wilmshurst and McGlone, 2005a). Pollen and spores with resistant exines, however, can be preferentially preserved together with biologically or chemically corroded palynomorphs (Schofield et al., 2007). During periods of soil erosion, these corroded grains can become incorporated into lake sediments (Wilmshurst and McGlone, 2005b).

In general, changes in pollen and spore concentrations in lacustrine sediments reflect changes in vegetation cover and sediment delivery to the lake. The vegetation cover around Lake Sapanca has changed little in the past 50 years, apart from the introduction of some invasive species and a slight reduction in forest cover due to construction of holiday homes, holiday resorts and timber exploitation.

\subsection{Chronology and detection of earthquakes}

A 6-cm-diametre Kajak gravity corer was used to retrieve 14 cores up to $45 \mathrm{~cm}$-long during the summer of 2003. The cores were collected along two transects across a strand of the NAFZ and in the deep central basin, south of the fault (Fig. 2). In order to avoid influence from building activities along the lakeshore and to have the most continuous records, the investigations focussed on cores taken in the lake centre. Details of sedimentological and geochemical studies of a $38.5-\mathrm{cm}$-long core from the central transect (SA03K7.1, 4043'05"N; 30¹6'05"E) and some other deep cores are reported in Schwab et al. (2009) and are briefly summarised here.

Five cores, including core SA03K7.2 (taken close to SA03K7.1), were dated using ${ }^{137} \mathrm{Cs}$ and ${ }^{210} \mathrm{~Pb}$ radionuclides. All cores show a similar 
chronology. The exponential ${ }^{210} \mathrm{~Pb}$ decay curve is interrupted by intervals with anomalous low values, which correspond to sedimentary disturbance events identified in sediment thin sections and from geochemical data. Background sedimentation rates were determined by subtracting event beds from the total core thickness. Peaks in ${ }^{137}$ Cs curves correspond to the peak in Pacific nuclear weapon testing around 1964 and the Chernobyl accident in 1986 (Schwab et al., 2009).

Based on their study of the short gravity cores, Schwab et al. (2009) inferred four anomalous sedimentary events that interrupted the normal background sedimentation in Lake Sapanca. $\mu$-XRF geochemistry showed that the event beds contained higher concentrations of elements derived from clastic sources. The most recent event (event 1 ) is marked by a turbidite (T1) and dates to the 1999 Izmit earthquake. Event 2 is a homogenite $(\mathrm{H})$ but only found in a single location. It seems to be unrelated to an earthquake and probably is the result of a local disturbance in the lake sedimentation (Fig. 2). Event 3 consists of both reworked material (R1 and R2) and turbidites (T2 and T3). It has been associated to the 1967 Mudurnu earthquake on the basis of its age. Event 4 is a turbidite (T4) and reworked material that may be attributed to the Abant earthquake in 1957.

The sedimentation mode in the lake progressively changes, as seen at around $14.5 \mathrm{~cm}$ depth in core K7 (Schwab et al., 2009): from more minerogenic to more organic (higher total carbon), from high values for many elements, such as $\mathrm{Si}$, to lower ones, from high to low magnetic susceptibility, from low to high water content, from high to low bulk density, and from absence of diatoms to abundant diatoms. Altogether these proxies suggest a high input of allochthonous clastic material in the older sediments. According to the chronology the sediments below $14.5 \mathrm{~cm}$ were laid down before $\sim 1985$ $(14.5 \mathrm{~cm})$.

\section{Material and methods}

\subsection{Modern samples and core sub-sampling}

Modern mud and moss samples (1-8 $\mathrm{ml}$ of sediment) were collected around Lake Sapanca, including the area between the lake and the Sakarya 
River, in July 2005 to determine the sources of sediment and palynomorphs reaching the lake (Fig. 2; Table 1). The mud fraction of all rivers flowing into the lake and the outflowing river was sampled at 29 locations, generally at lakeshore. Fifteen moss samples were collected from single polsters at the lakeshore, the mountains south of the lake and in the hills to the north. The tops of nine Kajak cores were also analysed (Fig. 2; Table 1).

Sixty-nine samples of sediment from core K7.1 were analysed for pollen, diatoms, lithology, total inorganic carbon, and total organic carbon. To allow for a well-coordinated multiproxy- analysis, small volumes and thicknesses, 0.4 to $1 \mathrm{ml}$ of sediment between 0.25 and $1 \mathrm{~cm}$ thick, had to be used for the pollen samples. Contiguous 0.25-cm-thick samples were taken between the core top and $10.25 \mathrm{~cm}$ depth and below this depth $0.25-\mathrm{cm}$-thick samples were taken and analysed at 1-cm spacing. Estimates of inter-event sedimentation rates range from 0.18 to $0.33 \mathrm{~cm} . \mathrm{yr}^{-1}$ indicating that each sample represents a few months to one year of time (Schwab et al., 2009).

\subsection{Treatment and identifications}

Palynological extractions were undertaken at Brunel University and at the University of Wales in Bangor (UK). All samples were successfully treated with $\mathrm{Na}_{4} \mathrm{P}_{2} \mathrm{O}_{7}, \mathrm{HCl}, \mathrm{HF}$ and $\mathrm{HCl}$, and sieved through 125 and $10 \mu \mathrm{m}$ screens, with no acetolysis, except for moss samples. Lycopodium tablets of known concentrations were added to all samples, except mosses, to determine concentrations of microfossils per millilitre of wet sediment. Pollen residues were mounted on glass slides with glycerol. Palynomorphs were counted under a light microscope at a magnification of $400 x$ routinely and at $1000 x$ for special identifications. An attempt was made to identify a minimum of 300 grains in each sample; smaller numbers were counted in samples with rare palynomorphs.

Pollen grains and spores were identified using the reference collection at Brunel University and the pollen atlas of Reille (1992, 1995, 1998). NPP include dinoflagellate cysts, which were identified using data from the Caspian Sea reported by Marret et al. (2004). Radiosperma, which is present in the Baltic and Aral seas, is generally considered a brackish and marine organism (Sorrel et al., 2006). It is rare in the Black Sea (P. Mudie, personal 
communication, 2008; Mudie et al., in press), but is present in the Caspian Sea (Leroy et al., 2007). Lake Sapanca sediments contain a diverse group of fungal spores. In addition to the spores shown in the pollen diagrams (Figs 4 and 5), Mycrothyrium, Tilletia and Sporormiella were observed and are included in the "fungal spores" curve.

Pollen preservation differs considerably in the modern samples. Of the 53 modern samples (Table 1), only 38 contained pollen and spores in sufficient numbers to be statistically meaningful: 14 out of 15 moss samples, 15 out of 29 river samples, and all 9 lake core tops.

\subsection{Palynological diagrams and statistical analyses}

Palynological diagrams were plotted using the software psimpoll4.10 (Bennett, 2007). All terrestrial and aquatic pollen grains and spores were included in the concentration values, whereas spore and non-pollen palynomorphs, which are mostly plankton and benthos, were excluded. All terrestrial pollen grains in the percentage diagram add up to $100 \%$ (i.e. the "sum" curve in the diagram, which is typically around 300). Aquatic plants and other microfossil remains are thus excluded from the sum and calculated as a percentage of the $100 \%$ terrestrial sum.

Statistical analysis was performed using psimpoll4.10 (Bennett, 2007). The zonation with CONISS after square-root transformation was made based on the taxa included in the sum, as well as the aquatics, spores, NPP and indeterminable and reworked grains. Detrended component analysis (DCA) was done on the same suite of palynomorphs (terrestrial, non-terrestrial and NPP) to identify those that best reflect the changes in the diagram (Bennett, 2007) (Fig. 6). After plotting the taxa eigenvectors on the first two axes, the taxa with the highest values on axes 1 and 2 were selected, along with Castanea, which is an excellent altitudinal indicator. Dinoflagellate thecae, Convolvulus, Sagina, non-psilate trilete spores and ostracod mandibles were not used. The distribution of the dinoflagellates differs according to preservation and the other four microfossils are too scarce to be statistically significant. A new diagram with the selected taxa was then plotted, focussed on the disturbance events (Figs 7a and b). A diagram of selected taxa representing the vegetation on the slopes around the lake and excluding three 
of the four sedimentary events has been prepared to show the general trend in vegetation through the period spanned by the core (Fig. 8).

\section{Results}

\subsection{Taxa list and vegetation}

The dominant arboreal pollen (AP) in surface samples are Pinus, deciduous Quercus, Fagus, Alnus, Cupressaceae, Carpinus betulus and Corylus; and non-arboreal pollen (NAP) are mainly Poaceae, AmaranthaceaeChenopodiaceae and Tubuliflorae (Fig. 4). Juglans, Pistacia, Castanea, evergreen Quercus, Oleaceae, Fraxinus excelsior, Platanus and Salix are consistently present. Pollen grains of recently introduced species such as Ailanthus altissima and Phacelia tanacetifolia occur in some samples.

Taxa characteristic of brackish and marine environments are also present, including Radiosperma, Spiniferites cruciformis, Brigantedinium and Impagidinium caspienense. These organisms may have entered Lake Sapanca when it was connected to the Black and the Marmara seas (Pfannenstiel, 1944), or alternatively may be the result of a recent reintroduction of fish (Innal and Erkakan, 2006). In either case, they appear to have developed a tolerance to freshwater.

Concentricystes is a palynomorph of unknown origin that may live in soil and is commonly associated with soil inwash (B. van Geel, personal communication, 1998). It also may live in lakes (Grenfell, 1995). Large quantities of fungal spores are interpreted to be inwash of soil material. Glomus (type 207) is particularly useful as it forms a symbiotic relationship with plant roots and is interpreted to be an indicator of erosion (van Geel et al., 2003).

\subsection{Modern samples}

Five moss samples are from the hills and shores north of Lake Sapanca; eight samples are from the mountains and shores, south of the lake; and one sample was collected in a gorge near River Sakarya (Figs 3 and 4; Table 1). Northern samples contain higher amounts of Quercus, Cistus, Amaranthaceae-Chenopodiaceae, Poaceae and Cerealia-type (t.) 
than in the southern samples. Some mosses above $1000 \mathrm{~m}$ asl in the southern mountains contain psilate monolete spores and Dryopteris filix-mast. spores. Altitudinal gradients are evident in the peaks of Juglans-CorylusAlnus at $354 \mathrm{~m}$ asl, Pinus at $425 \mathrm{~m}$ asl, Carpinus at $800 \mathrm{~m}$ asl, Castanea at $1039 \mathrm{~m}$ asl, Rhododendron at 1000-1100 m asl, Fagus at $1460 \mathrm{~m}$ asl, and the highest values of Abies pollen above $1000 \mathrm{~m}$ asl (Figs 2 and 4; Table 1).

Southern mosses and mud samples are richer in Carpinus betulus-t., Fagus, Rhododendron and Castanea than northern samples. The five southern delta samples have high values of Juglans. Liguliflorae and Brassicaceae are high in some northern mud samples and in the three samples from the floodplain between Lake Sapanca and the Sakarya River. Cyperaceae and Typhaceae percentages are particularly high in the samples from the floodplain between the lake and the Sakarya River. Fern spores are common only in mud samples from deltas on the south shore. Green algae and cyanobacteria occur in samples east of the lake. Concentricystes is present in only two samples: one along the Sakarya River and the other along the Istanbul River near the village of Guldibi. The three samples from the Sakarya River have relatively high values of Pinus and Salix.

Many of the lake delta and Sakarya River samples are sterile or contain few palynomorphs other than fungal spores (Table 1). Reworked pollen and spores are mostly found in the delta samples and in samples from the floodplain between Lake Sapanca and the Sakarya River. The impoverished nature of these assemblages is explained by the high soil content of the samples, the high energy of the depositional environment, and the oxygen-rich environments to which the palynomorphs are exposed.

Four sediment samples were taken from the centre of the lake and five samples were collected from the shallow western end of the lake. All lake sediment samples contain NPP and dinocysts and are the samples with the best palynomorph preservation. The samples from the west end of the lake are richer in Pinus, Cyperaceae, aquatic vegetation and fern spores than those from the lake centre. 


\subsection{Palynomorph assemblages in core K7.1}

Despite the high temporal resolution of sampling, intra-annual fluctuations in pollen production and successive flower blooming times cannot be seen in the data. It is likely that bioturbation is mixing the sediment at least at the annual scale (Fig. 5). However this bioturbation does not seem significant enough to blur the boundaries of event horizons, which in thin sections are well defined (Schwab et al., 2009).

Ten palynological zones $(\mathrm{pz})$ reflect changes in palynomorph assemblages through time in core K7 (Fig. 5). The main change occurs at around $16.6 \mathrm{~cm}$ depth.

Pollen concentrations range from 2,900 to 44,000 grains per $\mathrm{ml}$ and preservation is excellent, with very few damaged pollen and spores. From 38 to $16.4 \mathrm{~cm}$, pollen concentrations are less than 20,000 grains per $\mathrm{ml}$. The lowest concentrations are at 37-35 and $23-17 \mathrm{~cm}$. Above $16.6 \mathrm{~cm}$, pollen concentrations are mainly $>20,000$ grains per $\mathrm{ml}$. Within this upper part of the core, relatively low concentrations occur around $9.1 \mathrm{~cm}$ and $6.1-1.9 \mathrm{~cm}$.

The pollen diagram shows relatively constant background values of Alnus, Carpinus, Fagus, Corylus, deciduous Quercus, Juglans and Poaceae that may be considered normal for the lake sediment (pz K1, 4, 7-8 and 10) (Figs 5 and 8). Superimposed on this background are major variations in Pinus, Liguliflorae, fern spores, fungal spores and concentrations.

DCA on the samples shows the distribution of the ten palynological zones in relation to the first two axes (Fig. 6b). Axis one allows separation of the sequence into two parts - samples above and below about $15.5 \mathrm{~cm}$. Pz K1 to K6 plot on the right side of the diagram. Palynological samples associated with normal sedimentation in the lake are located near the centre of the plot. $\mathrm{Pz}$ K2-3, K6 and $\mathrm{K} 9$ lie at the positive end of axis 2.

Pz K2 and K3 $(37.6-34.5 \mathrm{~cm})$ display a continuous curve of Rhododendron (Fig. 5 and 7a). The two zones have high values of fern spores, indeterminable grains and reworked elements, especially the base of pz K2. Fungal spores and Glomus are dominant in the two zones. Pollen concentrations are the lowest among the core samples. 
Pz K5 (23.6-19.6 cm) has high values of Pinus (up to $45 \%$ ) and Liguliflorae (up to 21\%). Psilate trilete spores and Concentricystes are also present. The concentration diagram (Fig. 7b), however, does not show the pine increase. Pz K6 (19.6-16.6 cm) has high percentages of fern spores and reworked elements. Fungal spores and especially Glomus are abundant in pz K5-6. Both zones have low pollen concentrations.

Pz K9 (6.25-2 cm) contains common Rhododendron pollen grains. Fern spores are also present, but in low amounts. Concentrations vary considerably through this pollen zone, with some low values.

\subsection{Interpretation of palynological zones}

The palynological diagram with the disturbance taxa (Fig. 7) can be interpreted using modern samples and statistical results (DCA on taxa (not shown) and zonation). We indentify five groups of taxa; the taxa in each group display similar trend and have similar modes of transport to the lake (Figs 4 and 6). The first group includes the 'normal ' lake sediment palynomorphs (see below section 5.4). The other four groups comprise disturbance indicators. The assemblages associated with disturbance events reflect dilution of the background sediment deposited in the lake by large inputs of soil and river-transported sediment, which contain little pollen.

Group 2 consists of Liguliflorae, Lamiaceae, Concentricystes and Glomus. These palynomorphs are resistant to chemical corrosion and their presence is the result of differential preservation. Glomus and Concentricystes are indicators of soil erosion. This group is attributed to inwash of soil from shorelines or nearshore open areas, but away from deltas because of the lack of indicators of river transport. The dominance of group 2 coincides with low concentrations of palynomorphs (Figs 7a and b).

Group 3 consists of reworked and indeterminable grains, psilate trilete spores, Pteridium aquilinum and fungal spores. It is an intermediate between groups 2 and 4 . Its taxa are common in soils and river sediment. The concentration diagram (Fig. 7b) indicates that their contribution to the lake has been fairly constant over the period of record. High percentage values at times of the disturbance events are caused by relative decreases in the concentrations of most of the other taxa. 
Group 4 consists of psilate monolete spores, Asplenium, Dryopteris filix-mas-t. and Anthoceros spores. High frequencies of these fern and moss spores indicate derivation from soils in humid areas, such as along rivers.

Group 5 consists of Abies, Castanea and Rhododendron. Pollen grains of these taxa are derived from plants growing in the mountains south of the lake. This group also includes non-psilate monolete spores whose values change coincidentally with those of Abies, Castanea and Rhododendron (Fig. 6). Accordingly all these taxa are taken to indicate pollen and spore input from soils at high altitudes, south of Lake Sapanca.

The four groups of disturbance indicators are distributed through the core as follows (Fig. 7). Pz K2 and K6 contain groups 3, 4 and 5, and thus record inputs of soil material by rivers, including elements derived from the southern mountains. Pz K5 has a strong signature of group 2, clearly differentiating this zone from all others in the diagram. This zone records a significant input of soil materials near the lake shoreline, probably through mechanisms such as bank collapse. River transport is quasi excluded for this zone. Small increases of groups 4 and 5 in pz K9 record river transport from high elevations with no evidence of pollen derived from the shores of the lake. $\mathrm{Pz} \mathrm{K} 3$ is a transition zone comprising only a single sample.

In brief, the palynological events are clearly caused by dilution of the lake sediment by various types of soils and river sediment, which are respectively barren or poor in pollen.

\section{Discussion}

The discussion starts with the main shift in the middle of the core as it affects how the events are expressed in the sediment and the palynomorph assemblages. Then the discussion focuses on the events and the sources of palynomorphs. It finished by looking at the general trend in the evolution of vegetation in the area, outside of any event.

\subsection{Shift to a cleaner lake at $17-14 \mathrm{~cm}$}

The shift from relatively low pollen concentrations to relatively high ones at c. $16.6 \mathrm{~cm}$ depth, and the main change in the dendrogram between pz K6 and K7 (Figs 5 and 6), correspond to changes seen in the study by 
Schwab et al. (2009) - a decrease of detrital elements such as $\mathrm{Si}, \mathrm{Al}, \mathrm{K}$ and $\mathrm{Ti}$ at c. $14.5 \mathrm{~cm}$ and a the general increase in carbon above $15 \mathrm{~cm}$. These changes are evidence of a decrease in the delivery of clastic sediment to the lake. The shift occurs before the 1986 Chernobyl event. Possible causes include changes in land-clearing practices, the end of the main construction works around the lake and damming of rivers flowing into the lake. The last possibility is considered the most likely.

\subsection{Sedimentary and palynological events}

Comparison of events detected by thin sections and geochemical analyses (Schwab et al., 2009) and those inferred from pollen analyses reveal synchroneity of some events and other events that are seen only in sedimentology. The three turbidites, T1, T2 and T4 (the small T3 was not sampled for palynological analysis because it is too thin) lie at the positive end of axis 2 of the DCA plot (Fig. 6c). The two reworked zones (R1 and R2) plot at the lower right side of the diagram, and the homogenite $(H)$ plots at the lower left. Normal lake sediment plots near the centre of the diagram. The pollen zones relate in the following way to the inferred sedimentological changes (Fig. 7).

Event 4, which deposited the T4 turbidite, is attributed to the 1957 Abant earthquake. Pollen zones K2-3 correspond to the T4 turbidite, except that pz K3 ends $2 \mathrm{~cm}$ earlier, below the top of the turbidite layer. It is likely that the upper part of the turbiditic layer (T4) comprises lake sediment displaced from slopes higher in the lake, thus making it indiscernible by palynology. So this event is a succession of distinctive sediment packages: river-transported soils with altitudinal soils from the south mountains, topped by some lake sediment.

Event 3 is responsible two reworked layers (R2, and R1) and two turbidite layers (T3 and T2). It is attributed to the 1967 Mudurnu earthquake. Although a distinctive sediment layer, the signature of $\mathrm{R} 2$ cannot be seen in the pollen diagram. The pollen spectra and concentration are similar to those one might expect in 'normal' lake sediment. In contrast, R1 coincides with pz $\mathrm{K} 5$, which is attributed to sediment derived from exposed lakeshore. T2 corresponds exactly to $\mathrm{pz} \mathrm{K} 6$. So this event consists of sediment delivery first 
from the nearest to the core site and later from mountain watersheds far away. Lake sediment (R2), soil (R1) and finally a mix of river and montane soils (T2) are successively observed. The rupture zone of the Mudurnu earthquake, therefore, appears to have had a strong effect on Lake Sapanca. The rupture occurred along what Muller et al. (2003) and Gürbüz and Gürer (2008b) call the active mountain-front fault located along the foot of Samanlı Mountains (Figs 1b and 2). The level of Lake Sapanca fell $24 \mathrm{~cm}$ during the earthquake and remained at that level for 24 hours (Ceylan, 1990).

Event $2(\mathbf{H})$, which is recorded by a homogenite layer $(\mathrm{H})$ in only two cores at station $\mathrm{K} 7$, is attributed to an unknown local event, possibly anthropogenic in origin. Homogenite $\mathrm{H}$, which spans the end of $\mathrm{pz} \mathrm{K} 7$ and the beginning of $\mathrm{pz} \mathrm{K} 8$, is very poorly expressed in the pollen diagram, only by a drop in concentrations and a small peak of Liguliflorae at 9.6-8.9 cm depth. The sedimentary homogenite, therefore, is not homogenous in its pollen content.

Event 1 (T1) produced turbidite layer T1 and is attributed to the 1999 Kocaeli earthquake. T1 corresponds to Pz K9. The sediment is strongly influenced by inwash of soil and sediment from the mountains to the south of Lake Sapanca. The smaller impact of the 1999 earthquake relative to the 1957 and 1967 events is largely attributed to the construction of dams in the 1970s on rivers flowing into Lake Sapanca and the resulting interruption of the sediment supply. These engineering works were successful in reducing sediment delivery to the lake, although the 1999 earthquake caused more damage than the previous two.

\subsection{Sediment delivery mechanisms}

The flux of sediment and soils to Lake Sapanca increases during and following earthquakes. This palynological study provides evidence for four main sediment and soil sources (Fig. 9).

Firstly slumps and turbidity currents from steep slopes within the lake deliver sediment to the centre of the lake from both north and south sides of the basin. Gürbüz and Gürer (2008a) showed that most of the terrigenous sediment carried into Lake Sapanca today accumulates on the southern shore of the lake. This sediment is unstable and available for transport and 
redeposition in the deep central part of the lake following disturbances such as earthquakes or storms. Resuspension and redeposition deliver palynomorphs of group 1 and, to a lesser extent, all other groups to the lake centre.

Secondly, seiches, waves or a sudden change in lake level may destabilise the shallow areas of the lake and erode the shoreline. A small seiche was reported in Lake Sapanca near Eşme after the 1999 earthquake (A. Gürbüz, field observations), but no seiches have been reported during other historic earthquakes. More importantly, landslides and turbidites can produce internal and surface waves that can erode, respectively, underwater slopes and the shore. Coseismic landslides during the 1999 earthquake were mapped at three places by Lettis et al. (2002): one near Eşme and at two places near Sapanca Town. Landslides may be indicated by the presence of palynomorph groups 1 and 2, but the influence of other groups can also be felt.

Thirdly, onshore liquefaction and subsidence of deltas happened at the Sapanca Hotel during the earthquakes in 1967 and 1999 (Ambraseys and Zatopek, 1969; Bardet et al., 2000; Çetin et al., 2002). Palynomorphs of groups 1 and 4, and to a lesser extent of groups 3 and 5, are well represented in the sediments resulting from these historic earthquakes.

Fourthly, erosion entrains soil and sediment along river courses from their headwaters to the river mouths at Lake Sapanca. Photographs taken by the United States Geological Survey after the 1999 earthquake show turbid plumes of water in Lake Sapanca and at the mouths of nearby rivers (http://gees.usc.edu/GEER/Kocaeli/Sapanca\%20Lake.htm and http://gees.usc.edu/GEER/Kocaeli/Aerial\%20Survey.htm). Palynomorphs of groups 4 and 5 would be introduced by bank collapse and erosion. Group 3 palynomorphs would progressively be added along the lower reaches of rivers. After an earthquake, rain and aftershocks continue to deliver destabilised sediment to the lake, which may explain the presence of altitudinal pollen grains (group 5) in disturbance layers in Lake Sapanca. 


\subsection{Trend in vegetation changes}

A long-term trend diagram has been prepared by eliminating from the sequence the following disturbance zones: (1) pz K2, pz K3 and the lower part of $\mathrm{pz} \mathrm{K} 4$ which are products of event T4; (2) the top part of $\mathrm{pz} \mathrm{K} 4, \mathrm{pz} \mathrm{K5}$ and pz K6 to record event R2; and (3) pz K9 (Fig. 8). The reduced $18 \mathrm{~cm}$-long sequence shows that Corylus and Fraxinus ornus percentages slightly increase towards the top of the core. In the lake, Gloeotrichia, Spiniferites cruciformis, the other dinoflagellates and Tetraedron show increased percentages. Fagus and Amaranthaceae-Chenopodiaceae slightly decrease upwards (Figs 5 and 8). Zea mais is replaced upward by Secale. Therefore in the second half of the $20^{\text {th }}$ century, human activities and climatic change have had minimal effects on the pollen record when compared with seismic events 4,3 and 1.

\section{Conclusions}

Changes in concentration and assemblages of palynomorphs in the uppermost sediments in Lake Sapanca are related, in part, to large $20^{\text {th }}$ century earthquakes. The provenance of palynomorphs in sedimentary layers attributed to the earthquakes was determined by comparison with the pollen assemblages of modern sediment samples. Palynology provides a clear signal of different sediment and soil provenances and delivery mechanisms, including subaqueous slumps and turbidity currents, liquefaction and failure of shoreline sediments, and collapse and erosion of river banks in the mountains south of the lake. The location of Lake Sapanca in an area of high relief enhances some of these phenomena.

Lower-than-normal pollen concentrations reflect periods of anomalous delivery of soil and sediment to Lake Sapanca, from source sediments that are impoverished in pollen. A survey of modern soil and sediments around the lake, including deltas and moss polsters, indicated that the soils and sediments reworked during earthquakes have little pollen. Lake sediments derived from these materials are proportionally richer in spores and in pollen grains with resistant exines than sediments derived from other sources.

Of the four disturbance events identified by Schwab et al. (2009), three are recorded in the palynomorph assemblages of core SA03K7.1: historical 
earthquakes in the 1999 (Izmit), 1967 (Mudurnu) and 1957 (Abant). The 1999 earthquake is the least evident in the pollen, probably because dams constructed on rivers flowing into Lake Sapanca intercepted most of the sediment produced by the earthquake. The 1967 Mudurnu earthquake is the best expressed in the core, because of the proximity of the epicentre to the lake.

The 38.5-cm-long core described here contains as much displaced sediment as 'normal' lacustrine sediment. Researchers should consider such disproportionate representation of sediment produced by disturbance events when carrying out palaeoclimatic research on lake sediments in seismic areas.

The methods used in this study are novel and offer promise in palaeoseismic investigations in seismically active regions. They are, however, time-consuming if applied to longer cores at the same level of detail as used in this study.

\section{Acknowledgements}

We are grateful to Fatih Uysal (Ankara University) and Sébastien Bertrand (Brunel University) for help in collecting the modern samples and for providing the data on the region. We collected the short cores with the support M. Albay of the Faculty of Fisheries of Istanbul University. The core chronology is based on data from E. McGee (University College Dublin, Ireland) and was established with the help of P. Werner and M. Schwab (Brunel University). Multiproxy analysis of the Kayak cores was done by a group of researchers and students from Brunel University. The study was funded by the European Union as part of the EC Project RELIEF (EVG1-CT2002-00069). M. Turner (Brunel University), John Clague (Simon Fraser University) and Oliver Korup (Swiss Federal Research Institutes) helped improved the English of the manuscript. This paper is a contribution to IGCP Project 490, the ICSU Dark Nature project and the INQUA TERPRO Commission.

\section{References}

Akkoyunlu, A., İleri, R., 2003. Evaluation of eutrophication process in Lake 
Sapanca (Sakarya, Turkey). International Journal of Environment Pollution 19, 576-602.

Albay, M., Akçaalan, R., 2008. Effects of water quality and hydrologic drivers on periphyton colonization on Sparganium erectum in two Turkish lakes with different mixing regimes. Environmental Monitoring and Assessment 146, 171 181.

Ambraseys, N.N., Zatopek, A., 1969. The Mudurnu Valley, west Anatolia, Turkey, earthquake of 22 July 1967 . Bulletin of the Seismological Society of America 59, 521-589.

Andrieu, V., de Beaulieu, J.-L., Ponel, P., Reille, M., 1997. Les distorsions de l'enregistrement pollinique de l'histoire de la végétation du dernier cycle climatique: exemples de séquences lacustres du sud de la France.

Geobios 21, 191-202.

Bardet, J.P., Çetin, K.O., Lettis, W., Rathje, E., Rau, G., Seed, R.B., Ural, D., 2000. Soil liquefaction, landslides and subsidences. Earthquake Spectra 16, 141-162.

Barka, A., 1999. The 17 August 1999 Izmit earthquake. Science 285, 18581859.

Barka, A., Akyüz, S., Altunel, E., Sunal, G., Çakır, Z., Dikbaş, A., Yerli, B., Rockwell, T., Dolan, J., Hartleb, R., Dawson, T., Fumal, T., Langridge, R., Stenner, H., Christofferson, S., Tucker, A., Armijo, R., Meyer, B., Chabalier, J.B., Lettis, W., Page, W., Bachhuber, J., 2000. The August 17, 1999 Izmit earthquake, M-7.4, eastern Marmara region, Turkey: study of surface rupture and slip distribution. In The 1999 Izmit and Düzce Earthquakes: Preliminary Results, Barka A, Kozacı Ö, Akyüz S, Altunel E (eds). Istanbul Technological University, Istanbul, pp. 15-30.

Baykal, B.B., Gönenç, I.E., Meriç, M., Tanik, A., Tunay, O., 1996. An alternative approach for evaluation of lake water quality: Lake Sapanca - A case study from Turkey. Water Science and Technology 34, 73-81.

Beaudoin, A.B. and Reasoner, M.A., 1992. Evaluation of differential pollen deposition and pollen focussing from three Holocene intervals in sediments from O'Hara, Yoho National Park, British Columbia, Canada: intra-lake variability in pollen percentages, concentrations and influx. Review of Palaeobotany and Palynology 75, 103-131. 
Becker, A., Ferry, M., Monecke, K., Schnellmann, M., Giardini, D., 2005. Multiarchive paleoseimic record of late Pleistocene and Holocene strong earthquakes in Switzerland. Tectonophysics 400, 153-177.

Bennett, K., 2007. Psimpoll and pscomb programs for plotting and analysis. Version psimpoll 4.10. www.chrono.qub.ac.uk/psimpoll/psimpoll.html [accessed April 2009]

Birks, H.J.B., Birks, H.H., 1980. Quaternary Palaeoecology. Edward Arnold, London, $289 \mathrm{pp}$.

Caputo, R., Helly, B., 2008. The use of distinct disciplines to investigate past earthquakes. Tectonophysics 453, 1-4, 7-19.

Caputo, R., Pavlides, S.B., 2008. Earthquake geology: Methods and applications. Tectonophysics 453, 1-4, 1-6.

Çetin, K.O., Youd, T.L., Seed, R.B., Bray, J.D., Sancio, R., Lettis, W., Yılmaz, M.T., Durgunoglu, T., 2002. Liquefaction-induced ground deformations at Hotel Sapanca during Kocaeli (İzmit), Turkey, earthquake. International Journal of Soil Dynamics and Earthquake Engineering 22, 1083-1092.

Ceylan, M.A., 1990. Sapanca Gölü'nün Hidrolojik etüdü (The hydrological research of Lake Sapanca). Unpublished M.Sc. thesis, Institute of Social Sciences of İstanbul, İstanbul (in Turkish).

Cowan, H.A., McGlone, M.S. 1991. Late Holocene displacements and characteristic earthquakes on the Hope River segment of the Hope Fault, New Zealand. Journal of the Royal Society of New Zealand 21, 373-384.

De Busk, G.H., 1997. The distribution of pollen in the surface sediments of Lake Malawi, Africa, and the transport of pollen in large lakes. Review of Palaeobotany and Palynology 97, 123-153.

Devlet Su İşleri (State Hydraulics Works), 1984. Sapanca Gölü kirlilik araştırması (Pollution study of Lake Sapanca). DSI Technical Report, Department of Drinking Water and Sewer System, Ankara, 135 pp. (in Turkish).

Doğan, A., 2004. Sakarya Havzası (Plio-Kuvaterner) Güney Kesimi Holosen İstifinin Sedimanter Özellikleri ve Jeolojik Evrimi (Sedimentary characteristic and geologic evolution of the south segment of Holocene stack of the Sakarya Basin (Pliocene-Quaternary)). M.Sc. thesis, University of Ankara, Graduate School of Natural and Applied Science (in Turkish). 
Doig, R., 1986. A method for determining the frequency of large-magnitude earthquakes using lake sediment. Canadian Journal of Earth Sciences 23, 930-937.

Elektrik İşleri Etüd İdaresi (General Directorate of Electrical Power Resources and Survey and Development Administration of Turkey), 2002. Göl Seviyeleri (Turkish lake level changes). Elektrik İşleri Etüd İdaresi Genel Müdürlüğü, Ankara, pp. 73-79 (in Turkish).

Ertürk, O., 1994. Geology, minerological and geochemical analysis of Sapanca Lake bottom sediments. Ph.D. thesis, Istanbul University, Graduate School of Natural and Applied Sciences, Istanbul, 113 pp. (in Turkish, with English abstract).

Grenfell, H., 1995. Probable fossil zygnematacean algal spore genera. Review of Palaeobotany and Palynology 84, 201-220.

Gürbüz, A., 2009. Orientations of palaeotectonic features as a key to understanding the neotectonic block rotation of the Kocaeli peninsula, NW Turkey. International Geology Review 51, 329-344.

Gürbüz, A., Gürer, Ö.F., 2008a. Anthropogenic affects on lake sedimentation process: a case study from lake Sapanca, NW Turkey. Environmental Geology 56, 299-307.

Gürbüz, A., Gürer, Ö.F., 2008b. Tectonic geomorphology of the North Anatolian Fault Zone in the Lake Sapanca basin (eastern Marmara region, Turkey). Geosciences Journal 12, 3, $215-225$.

Gürbüz, A., Gürer, Ö.F., 2008c. Sapanca Gölü'nün oluşumu ve beslenme havzasının jeolojisi, hidrolojisi ve depremselliği (The setting of Lake Sapanca and hydrology, geology and seismotectonics of drainage basin). In Lake Sapanca, Okgerman H, Altuğ G (eds). Istanbul University Press, Istanbul, 12 pp. (in Turkish).

Gürbüz, A., Leroy, S.A.G., accepted. Science versus myth: Was there a connection between the Marmara Sea and Lake Sapanca? Journal of Quaternary Sciences.

Hughes, J.F., Mathewes, R.W., Clague, J.J., 2002. Use of pollen and vascular plants to estimate coseismic subsidence at a tidal marsh near Tofino, British Columbia. Palaeogeography, Palaeoclimatology, Palaeoecology 185, 145-161. 
Innal, D., Erkakan, F., 2006. Effects of exotic and translocated fish species in the inland waters of Turkey. Reviews in Fish Biology and Fisheries 16, 3950.

Kürçer, A., Chatzipetros, A., Tutkun, S. Z., Pavlides, S., Ateş, Ö., Valkaniotis, S., 2008. The Yenice-Gönen active fault (NW Turkey): Active tectonics and palaeoseismology. Tectonophysics 453, 1-4, 263-275

Leroy, S.A.G., 1992. Palynological evidence of Azolla nilotica Dec. in recent Holocene of eastern Nile Delta, and its environment. Vegetation History and Archaeobotany 1, 43-52.

Leroy, S.A.G., Marret, F., Gibert, E., Chalié, F., Reyss, J.-L., Arpe, K., 2007. River inflow and salinity changes in the Caspian Sea during the last 5500 years. Quaternary Science Reviews 26, 3359-3383.

Lettis, W., Bachhuber, J., Barka, A., Witter, R., Brankman, C., 2000. Surface fault rupture and segmentation during the Kocaeli earthquake. In The 1999 Izmit and Düzce Earthquakes: Preliminary Results, Barka, A., Kozacı. Ö., Akyüz, S., Altunel, E. (eds). Istanbul Technical University, Istanbul. pp. 3154.

Lettis, W., Bachhuber, J., Witter, R., Brankman, C., Randolph, C.E., Barka, A., Page, W.D., Kaya, A., 2002. Influence of releasing step-overs on surface fault rupture and fault segmentation: examples from the 17 August 1999 Izmit earthquake on the North Anatolian Fault, Turkey. Bulletin of the Seismological Society of America 92, 19-42.

Marret, F., Leroy, S.A.G., Chalié, F., Gasse, F.. 2004. New organic-walled dinoflagellate cysts from recent sediments of central Asian seas. Review of Palaeobotany and Palynology 129, 1-20.

Mathewes, R.W., Clague J.J., 1994. Detection of large prehistoric earthquakes in the Pacific Northwest by microfossil analysis. Science 264, 688-691.

Mirecki, J.E., 1996. Recognition of the 1811-1812 New Madrid earthquakes in Reelfoot Lake, Tennessee sediments using pollen data. Journal of Paleolimnology 15, 183-191.

Morkoç, E., Tuğrul, S., Öztürk, M., Tüfekçi, H., Egesel, L., Tüfekçi ,V., Okay, O.S., Legović. T., 1998. Trophic characteristics of the Sapanca lake (Turkey). Croatica Chemica Acta 71, 303-322. 
Mudie, P.J, Leroy, S.A.G., Marret, F., Gerasimenko, N., Kholeif, S.E.A., Sapelko, T., Filipova-Marinova, M., in press. Non-pollen palynomorphs (NPP): indicators of salinity and environmental change in the Black SeaMediterranean corridor. In: Buynevich, I, Yanko-Hombach, V, Smyntyna, O, Martin, R. (eds). Geology and Geoarchaeology of the Black Sea Region: Beyond the Flood Hypothesis. Geological Society of America Special Paper.

Müller, J.R., Aydin, A., Maerten, F., 2003. Investigating the transition between the 1967 Mudurnu Valley and the 1999 Izmit earthquakes along the North Anatolian fault with static stress changes. Geophysical Journal International 154, 471-482.

Pantosti, D., Pucci. S,, Palyvos, N., De Martini, P.M., D'Addezio, G., Collins, P.E.F., Zabci, C., 2008. Paleoearthquakes of the Düzce fault (North Anatolian Fault Zone): Insights for large surface faulting earthquake recurrence. Journal of Geophysical Research 113, B01309.

Parsons, T., 2004. Recalculated probability of $M \geq 7$ earthquakes beneath the Sea of Marmara, Turkey. Journal of Geophysical Research 109, B05304, doi:10.1029/2003JB002667.

Pennington, W., 1979. The origin of pollen in lake sediments: an enclosed lake compared with one receiving inflow streams. The New Phytologist 83, 189-213.

Pfannenstiel, M., 1944. Die diluvialen Entwicklungstadien und die Urgeschichte von Dardanellen, Marmarameer und Bosporus. Geologische Rundschau 43, 342-434.

Quézel, P., Barbero, M., 1985. Carte de la végétation potentielle de la région Méditerranéenne. Feuille 1: Méditerranée Orientale. Editions du Centre Nationale de la Recherche Scientifique, Paris, scale 1:2,500,000.

Rathje, E.M., Karatas, I., Wright, S., Bachhuber, J., 2004. Coastal failures during the 1999 Kocaeli earthquake in Turkey. Soil Dynamics and Earthquake Engineering 24, 699-712.

Reille, M., 1992. Pollen et Spores d'Europe et d'Afrique du Nord. Laboratoire de Botanique Historique et Palynologie, Marseille, 543 pp.

Reille, M., 1995. Pollen et Spores d'Europe et d'Afrique du Nord, Supplément 1. Laboratoire de Botanique Historique et Palynologie, Marseille, 331 pp. 
Reille, M., 1998. Pollen et Spores d'Europe et d'Afrique du Nord, Supplément 2. Laboratoire de Botanique Historique et Palynologie, Marseille, 521 pp.

Russell, R.J., 1954. Alluvial morphology of Anatolian rivers. Annals of the Association of American Geographers 44, 363-391.

Şahin, M., Tarı, E., 2000. The August 17 Kocaeli and the November 12 Düzce earthquakes in Turkey. Earth Planets Space 52, 753-757.

Schofield, J.E., Edwards, K.J., McCullen, J.A., 2007. Modern pollenvegetation relationships in subarctic southern Greenland and the interpretation of fossil pollen data from the Norse landnám. Journal of Biogeography 34, 473-488.

Schwab, M., Werner, P., Dulski, P., McGee, E., Nowaczyk, N., Bertrand, S., Leroy, S.A.G., 2009. Palaeolimnology of Lake Sapanca and identification of historic earthquake signals, Northern Anatolian Fault Zone (Turkey). Quaternary Science Reviews 28, 991-1005.

Sorrel, P., Popescu, S.-M., Head, M.J., Suc, J.-P., Klotz, S., Oberhänsli, H., 2006. Hydrographic development of the Aral Sea during the last 2000 years based on a quantitative analysis of dinoflagellate cysts.

Palaeogeography, Palaeoclimatology, Palaeoecology 234, 304-327.

Straub, C., Kahle, H.-G., Schindler, C., 1997. GPS and geologic estimates of the tectonic activity in the Marmara Sea region, NW Anatolia. Journal of Geophysical Research 102, 27587-27602.

Syvitski, J.P.M., Schafer, C.T., 1996. Evidence for an earthquake-triggered basin collapse in Saguenay Fjord, Canada. Sedimentary Geology 104, 1-4, 127-153.

Ternek, Z., 1964. Geologic map of Turkey, Istanbul, and Zonguldak sheets. Institute of Mineral Research and Exploration, Ankara, scale 1:500,000.

Union of Municipalities of the Marmara Region, no date. http://www.marmara.gov.tr/Default en.htm (accessed March 2009).

United States Geological Survey. gees.usc.edu/GEER/Kocaeli/Sapanca\%20Lake.htm and gees.usc.edu/GEER/Kocaeli/Aerial\%20Survey.htm (accessed 22 May 2008).

Vandenberghe, D., Vanneste, K., Verbeeck, K., Paulissen, E., Buylaert, J.-P., De Corte, F., Van den haute, P., 2009. Late Weichselian and Holocene 
earthquake events along the Geleen fault in NE Belgium: OSL age constraints. Quaternary International, 199, 1-2, 56-74.

Van Geel, B., 2003. Environmental reconstruction of a Roman Period settlement site in Uitgeest (The Netherlands), with special reference to coprophilous fungi. Journal of Archaeological Sciences 30, 873-883.

Wilmshurst, J.M., McGlone, M.S., 2005a. Origin of pollen spores in surface lake sediments: comparison of modern palynomorphs assemblages in moss cushions, surface soils and surface lake sediments. Review of Palaeobotany and Palynology 136, 1-15.

Wilmshurst, J.M., McGlone, M.S., 2005b. Corroded pollen and spores as indicators of changing lake sediment sources and catchment disturbance. Journal of Paleolimnology 34, 503-517.

Yalçın, N., Sevinç, V., 2001. Heavy metal contents of Lake Sapanca. Turkish Journal of Chemistry 25, 521-525.

Yılmaz, B., 2000. Sapanca Gölü su havzasının flora ve faunasının araştırılması. (Research on the flora and fauna in the drainage area of Sapanca Lake). M.Sc. thesis, Institute of Science, Sakarya University, 41 pp. (in Turkish). 


\section{Captions}

Fig. 1. a) Location of Lake Sapanca in NW Turkey. MS = Marmara Sea, NAFZ $=$ North Anatolian Fault Zone. Black dot in dashed box = Lake Sapanca. $b$ ) Active faults near Lake Sapanca (modified from Lettis et al., 2000). LS = Lake Sapanca.

Fig. 2. Sample sites in and around Lake Sapanca. Sample numbers correspond to those in Table 1. Symbols: white conifer trees = moss samples, bold $\mathrm{X}=$ lake core tops, black flowers $=$ river samples. Core SA03K7.1 is located in the lake centre at coring station 7 , under the cross numbered 7 .

Fig. 3. Map of vegetation around Lake Sapanca (modified from Ceylan 1990).

Fig. 4. Percentage palynological diagram for modern samples collected in and around Lake Sapanca. Black dots are values less than $0.075 \%$. $\mathrm{N}=$ north, $\mathrm{S}=$ south, $\mathrm{W}=$ west, $\mathrm{E}=$ east, $\mathrm{C}=$ lake centre, $\mathrm{R}=$ Sakarya River and surroundings.

Fig. 5. Percentage palynological diagram of core SA03K7.1. Black dots are for values less than $0.25 \%$. Horizontal exaggeration is $10 x$.

Fig. 6. Results of detrended component analysis for samples from core SA03K7.1 on axis one (horizontal) and axis two (vertical). Relations between (a) pollen zones, events and earthquakes; (b) pollen zones; and (c) sedimentary events.

Fig. 7. Palynological diagram of selected disturbance indicators in core SA03K7.1. (a) Percentages, and (b) Concentrations.

Fig. 8. Pollen diagram for selected taxa with the sediment related to earthquake removed. Horizontal exaggeration is 10x.

Fig. 9. Schematic representation of palynomorph sources by groups. 